\title{
Influence of surface water level fluctuation and riverbed sediment deposits on groundwater regime
}

\author{
Márta Koczka Bara, Yvetta Velísková*, Renáta Dulovičová, Radoslav Schügerl \\ Institute of Hydrology, Slovak Academy of Sciences, Račianska 75, 83102 Bratislava, Slovak Republic. \\ ${ }^{*}$ Corresponding author. Tel.: +4212 49268255. Fax:+4212 44259404. E-mail: veliskova@uh.savba.sk
}

\begin{abstract}
The spatial and temporal patterns of surface water (SW) - groundwater (GW) exchange are significantly affected by riverbed silting, clogging or erosion processes, by altering the thickness and hydraulic conductivity of riverbed sediments. The duration of SW-GW exchange is controlled by the drainage and infiltration resistance of river bottom sediments (e.g. Andrássy et al., 2012). Generally, these two parameters primarily depend on the hydraulic conductivity and on the thickness of clogged layer.

In this study the flow processes between GW and SW were modeled by model TRIWACO for different infiltration resistance and drainage resistance of riverbed sediments. The model area is situated on the Rye Island, which is a lowland area with very low slope. In this area a channel network was built up, where the flow conditions are controlled by water-gates. Because of the low slope and the system of water gates built on the channels, the riverbeds are influenced by intensive clogging processes. First, the applicability of model TRIWACO in the study area was tested by modelling the response of GW on SW level fluctuation. It was simulated, how the regulation of water level and flow direction in the channels influence the GW level, especially in extreme hydrological conditions (drought/flood), and if the GW flow direction and GW level change as it was expected. Next, the influence of channel network silting up on GW-SW interaction was modeled. The thickness of riverbed sediments was measured and their hydraulic conductivity from disturbed sediment samples was evaluated. The assessed hydraulic conductivity was used to calculate the infiltration resistance and the drainage resistance of riverbed sediments in the study area. Then, the GW level and flow direction was simulated for different infiltration resistance and drainage resistance of sediments.
\end{abstract}

Keywords: Surface water - groundwater interaction; Groundwater flow modelling; Infiltration/drainage resistance of rivers.

\section{INTRODUCTION}

Surface water (SW) and groundwater (GW) are the main sources for drinking water supply and important resources also for industry and agriculture. These two components of the hydrological cycle are interconnected and are affecting each other, as well as the natural environment. The EU Water Framework Directive addressed the need of a sustainable management of coupled GW-SW resources and their ecosystems and recommends estimating the exchange flow rates and flow directions between SW and GW. Within an open channel system, the interaction between SW and GW perform through a three-dimensional saturated interstitial area beneath and alongside the stream, where GW and SW mixing occurs over several different spatial and temporal scales (Mallard et al., 2002; White, 1993). The flow dynamics and the exchange of water, solutes and colloids between SW and GW in this zone are influenced by many factors and conditions. Stream-aquifer interactions are significantly affected by riverbed silting, clogging or erosion processes, by altering the thickness and hydraulic conductivity of riverbed sediments and the topmost layers of soils. The duration of SW-GW exchange depends on the drainage resistance and infiltration resistance of river bottom sediments (e.g. Andrássy et al., 2012), which are affected by the hydraulic conductivity and the thickness of the sediments.

In the last few decades the various aspects of GW and SW interactions were investigated by many authors. A general overview on numerical solutions of GW-SW interaction and a theoretical and practical application of integrated surfacesubsurface models are given by e.g. Fleckenstein et al. (2010),
Derx et al. (2010), and Burger (2007, 2008 and 2011). The hydraulic connection and dynamics of water exchange between the river and the aquifer were simulated by e.g. Dulovičová and Kosorin (2007), and Peyrard et al. (2008). The relationships between river bed morphology and water infiltration were investigated in e.g. Storey et al. (2003), Cardenas et al. (2004), and Frei et al. (2009). River bed clogging processes were studied in e.g. Gutknecht et al. (1996), Blaschke et al. (2003), and Dulovičová and Velísková (2011a).

Field and laboratory experiments may reach its limits regarding scale and complexity of natural processes; therefore numerical hydrological models can be used for improving the understanding of GW flow dynamics and their interaction with SW. A hydrological model is a simplified scheme of certain physical or ideal objects, describing the basic properties, relationships and rules of the system of its prototype (original, sample). A model is very useful to study and predict the effects of different processes and mechanisms; nevertheless a model can never fully describe all the natural processes. In recent years considerable amount of scientific works were dealing with hydrological processes modeling; integrated surface-subsurface numerical models have been refined and enhanced significantly and have improved our understanding of processes and dynamics (Fleckenstein et al., 2010). Also Brunner et al. (2009) is dealing with spatial and temporal aspects of the flow transition from connection to disconnection between SW and GW. They show that the state of connection is a critical variable in the dynamics of infiltration in a non-steady system. However, the model used in this paper, TRIWACO, is not able to simulate transitional stages between the two flow regimes, what may lead to errors in simulations (Brunner et al., 2010). One of the 
aims of this study was to test the model TRIWACO applicability to simulate the reaction of $\mathrm{GW}$ on channel bed silting in the study area. Our main interest was to demonstrate the influence of channels silting on $\mathrm{GW}$ flow direction, rather than get exact values of GW heads. Yet TRIWACO is a simple model, it was considered to be suitable to solve this task in the study area.

In this pilot study, the interaction between GW and SW and the dynamics of flow processes in the GW-SW system was simulated by the model TRIWACO and the influence of riverbed silting on the GW regime was tested. The model area is situated on the Rye Island, which is a lowland area with very low slope. In this area a channel network was built up, which serves for drainage primarily. Because of the low slope and the system of water gates built on the channels, the riverbeds are influenced by intensive clogging processes. The objective of the study was to demonstrate the effect of channels silting on the surrounding GW by using different infiltration and drainage resistance of riverbed sediments in the simulations. First, the chosen model TRIWACO was tested by modelling the influence of SW level fluctuation on the GW regime. It was simulated, how the regulation of water level in the channels influences the GW level, especially in extreme hydrological conditions (drought/flood). It was evaluated if the GW flow direction and GW level changed according to our previous assumptions. Afterwards the influence of channel network silting on the surrounding GW was investigated. Thick sediment deposits can totally disconnect the communication between SW and GW, what can negatively affect the flora and fauna in the channels and in the soils around. The maintenance of channels and the removal of riverbed sediments is time-consuming and financially demanding. The study aims to support the channel maintenance and confirm the importance of regular sediment removal. In the model area the thickness of riverbed sediments was measured and their hydraulic conductivity from disturbed sediment samples was evaluated. The assessed hydraulic conductivity was used to calculate the infiltration resistance and the drainage resistance of the silts in the channels. These two parameters control the duration of SW-GW exchange. Different infiltration resistance and drainage resistance of riverbed sediments were used for the simulations of channels silting influence on the GW regime.

\section{MODELING OF GW-SW INTERACTION WITH TRIWACO}

For the simulation of hydraulic processes between GW and SW various numerical models were developed, with different levels of complexity and completion. In this study, model TRIWACO was chosen for solving the problem of GW-SW interaction. Model TRIWACO has been developed by Dutch company Royal Haskoning. The model offers an integrated modeling environment for unsaturated, saturated, drainage/infiltration and surface water flow (Royal Haskoning, 2004). The model was built for solving GW flow and solute transport in horizontal plane, and it allows simulating water flow in several hydrogeological layers - aquifers. The model can also be coupled to a hydrodynamic SW model. The working environment is designed in such a way that it provides the user with real time information on modeling progress (Royal Haskoning, 2004). The model assures easy linkage to geographic information systems (GIS), what allows the utilization of GIS data and maps as model inputs and the results can directly be visualized. One of the distinct advantages of TRIWACO is its modular structure and flexibility. Various modules are available for SW flow, GW recharge and unsatura- ted zone, GW flow in saturated zone, water balance, path lines and solute transport, pumping wells and other modules (Royal Haskoning, 2004).

\section{Mathematical background}

The flow simulation in TRIWACO is solved by partial differential equation which follows from Darcy's law and the equation of continuity, and the Finite Element formulation of these equations. In the derivation of the partial differential equations the Dupuit-Forchheimer assumption is used, so that the partial differential equation can be written in terms of the potential groundwater head $h$ as (Royal Haskoning, 2004):

$$
\begin{gathered}
\frac{\partial}{\partial x}\left[T_{x x} \frac{\partial h}{\partial x}\right]+\frac{\partial}{\partial x}\left[T_{x y} \frac{\partial h}{\partial y}\right]+\frac{\partial}{\partial y}\left[T_{y x} \frac{\partial h}{\partial x}\right]+ \\
+\frac{\partial}{\partial y}\left[T_{y y} \frac{\partial h}{\partial y}\right]+q=S \frac{\partial h}{\partial t}
\end{gathered}
$$

There are no restrictions on the transmissivity tensor $T$. Therefore, the transmissivity can be anisotropic, while the principal directions do not coincide with the coordinate axes. For a multi-aquifer system, the Equation (1) holds for each aquifer. The aquifers are coupled through the recharge term $q$ (Royal Haskoning, 2004). The recharge term $q$ comprises a number of different effects. In TRIWACO $q$ is divided into four distinctive components, depending on the origin of the water (Royal Haskoning, 2004):

- $\quad q_{a}$ - recharge from a top-system at the top of the uppermost aquifer due to e.g. precipitation, infiltration etc.;

- $\quad q_{l}-$ recharge due to leakage through the separating aquitards between aquifers;

- $\quad q_{r}$ - recharge/discharge from rivers, canals and drains (line sinks);

- $\quad q_{s}$ - recharge/discharge from sources or point sinks.

The Finite Element equations are derived from the partial differential Equation (1). Subdividing the recharge term $q$ in four distinctive components, this equation is written as:

$$
\begin{aligned}
& \frac{\partial}{\partial x}\left[T_{x x} \frac{\partial h}{\partial x}\right]+\frac{\partial}{\partial x}\left[T_{x y} \frac{\partial h}{\partial y}\right]+\frac{\partial}{\partial y}\left[T_{y x} \frac{\partial h}{\partial x}\right]+\frac{\partial}{\partial y}\left[T_{y y} \frac{\partial h}{\partial y}\right]+ \\
& +q_{a}+q_{l}+q_{r}+q_{s}=S \frac{\partial h}{\partial t} .
\end{aligned}
$$

The Finite Element equations are derived using Galerkin's method. The resulting Finite Element equations will generally form a system of nonlinear equations, mainly due to the nonlinear character of the recharge term $q$. For detailed description the reader is referred to the TRIWACO User's manual (Royal Haskoning, 2004).

In this study, we focused on interaction processes through the riverbed and banks, e.g. the recharge/discharge from the channels to the aquifer and vice versa. The discharge from or the recharge into the channels may be defined in two ways:

- the water level (piezometric head) in the channel is given and TRIWACO will calculate the water flow;

- water flow (infiltration, drainage) is given and TRIWACO computes the water level in the river (channel).

At each river point the inflow or drainage rate is computed by (Royal Haskoning, 2004):

$Q_{r}=A_{r} \frac{\left(h_{r}-h\right)}{C_{r}}$

where $Q_{r}\left[\mathrm{~m}^{3} \cdot \mathrm{s}^{-1}\right]$ is infiltration or drainage rate; $A_{r}\left[\mathrm{~m}^{2}\right]$ is the 
area of the river in the given point, computed from the length of the river assigned to the point and the hydraulic radius of the river at that point; $h$ [m a.s.1.] is the groundwater head in the aquifer (calculeted by the model); $h_{r}$ [m a.s.l.] is the water level in the river (channel) and $C_{r}$ [day] is the resistance of the river. The river resistance $C_{r}$ in natural conditions usually has different values for infiltration $\left(h_{r}>h\right)$ and for drainage $\left(h_{r}<h\right)$ (Royal Haskoning, 2004). Model TRIWACO offers the possibility to define a different resistance for drainage $(C D)$ and for infiltration $(C I)$.

\section{STUDY AREA AND MODEL SETUP General overview}

The study area is situated on the Rye Island (Žitný Ostrov). Rye Island is one of the most productive agricultural areas of Slovakia. It is situated on the Danube Lowland, between the Danube River and the Small Danube River. The Rye Island is the biggest river island in Europe, with an area of almost $1900 \mathrm{~km}^{2}$. Under its surface is the richest water reservoir of Slovakia and also of Eastern Europe: according to the Water Management Balance (WRI, 2005) there are 10 milliard $\mathrm{m}^{3}$ of drinking water, what means $18 \mathrm{~m}^{3} \cdot \mathrm{s}^{-1}$ of available $\mathrm{GW}$ resources. For this reason it is very important to deal with quantity and quality of water resources in this region.

The Rye Island is a lowland area with very low slope: its average slope is only about $2.5 \times 10^{-4}$. That was one of the reasons for building up a channel network in this area, which serves for drainage and irrigation. On Figure 1 the map of Rye Island and the main channels are displayed. Because of the low slope and the system of water gates built on the channels, the riverbeds are influenced by intensive clogging processes (Dulovičová and Velísková, 2010).

\section{Model area and input data}

The input or initial data set defines the conceptual model. In model TRIWACO, the discharge or recharge of groundwater at the top of the aquifer can be characterized by the so-called topsystems. A top-system describes the interaction between the groundwater system and the drainage/infiltration system consi- sting of surface waters and drains. In this case study the topsystem number 1 was selected, where the groundwater recharge is considered to be equal to the precipitation excess. According to the selected top-system, the model generates an initial data- and parameter set. TRIWACO generates the following physical parameters: parameters describing the climatic conditions, surface parameters, parameters describing hydrogeological conditions, surface water parameters with respect to the geometry and resistances of the drainage system and source parameters. The initial parameter set can be extended by more parameters, either internal or user defined.

The model area was selected in the watershed of the Chotarny Channel, approximately between 5 and 9 river km $(\mathrm{rkm})$, where three other channels flow into the Chotarny Channel: Belsky Channel, Komarnansky Channel and Kratky Channel. The Chotarny Channel, which is situated in the middle-east part of the Rye Island, is one of the largest channels of the network. Its length is about $28 \mathrm{~km}$, channel width ranges from $8 \mathrm{~m}$ to $17 \mathrm{~m}$. In natural conditions its flow direction is from the South to the North (from the Danube River to the Small Danube River), however the flow direction and water level in the channel can be regulated by a system of water gates. Belský Channel is a left-side tributary of Chotarny Channel, at $6.25 \mathrm{rkm}$. The channel is approximately $9 \mathrm{~km}$ long, and its average width is $8-10 \mathrm{~m}$. Komarnansky Channel is a right-side tributary of Chotarny Channel at $8.8 \mathrm{rkm}$; its length is $28 \mathrm{~km}$, with average width 10-12 m. Kratky Channel, a left-side tributary of Chotarny Channel at $9.1 \mathrm{rkm}$, is the shortest stream in the study area with cca $2 \mathrm{~km}$ length. Its average water level is around $0.8 \mathrm{~m}$, but in drought periods it can be close to zero. Komarnansky and Kratky Channel are closed from Chotarny Channel by water-gates.

The model area is approximately $8.5 \mathrm{~km}^{2}$. Its surface is very flat; the heights of terrain vary from 109.8 to $110.0 \mathrm{~m}$ a.s.l. The study area belongs to the warm, very dry climatic region, with mild winter. The mean annual air temperature in this area is above $10^{\circ} \mathrm{C}$; the mean annual potential evapotranspiration is $750 \mathrm{~mm}$ and the mean annual actual evapotranspiration is more than $450 \mathrm{~mm}$. The mean annual precipitation total is about $500 \mathrm{~mm}$ (Miklós et al., 2002) and the mean annual effective rainfall in this area is less than $50 \mathrm{~mm}$ (Švasta and Malík, 2006).

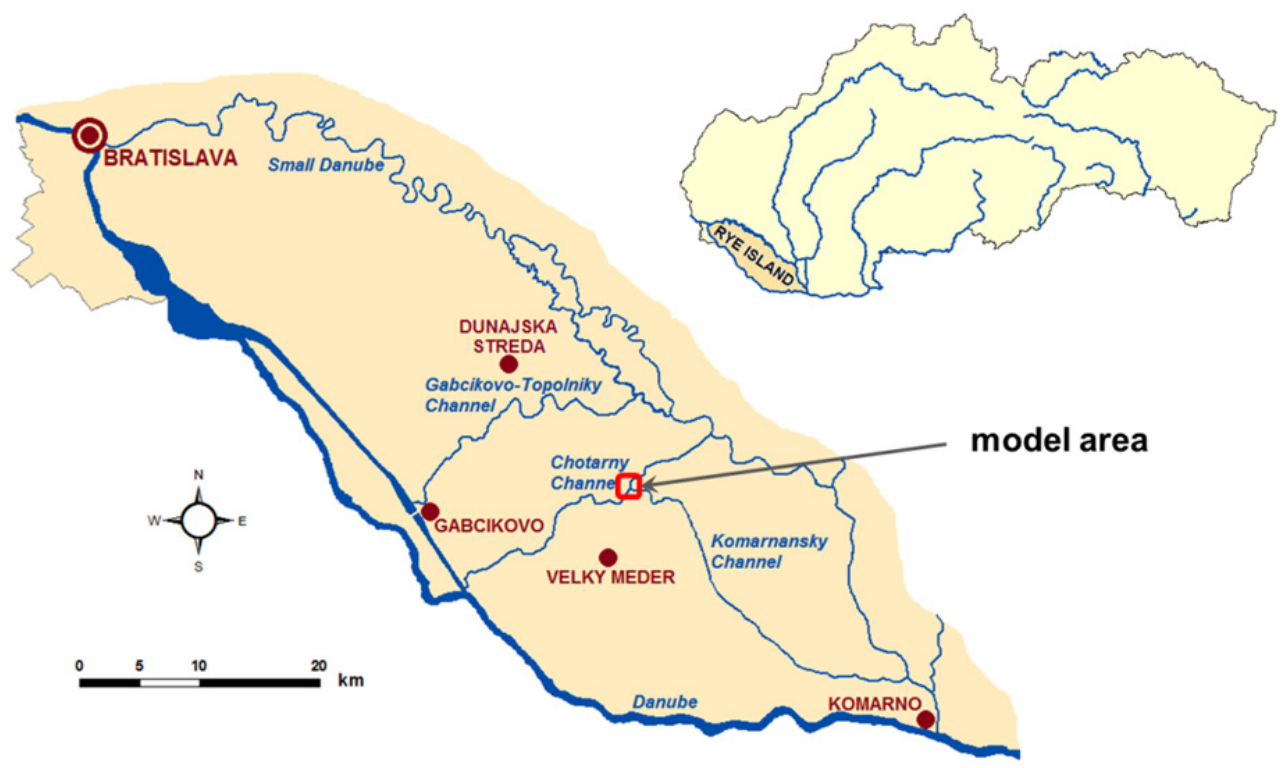

Fig. 1. Map of the Rye Island. 
From hydrogeological point of wiev, the model area is built by sediment deposits of the Danube River; the water-bearing layer is created dominantly by gravels and sands of pleistocenholocen with intergranular permeability. In the model, one aquifer with steady-state groundwater flow was considered. The thickness of the aquifer is about $50 \mathrm{~m}$; the height of the base is around $60 \mathrm{~m}$ a.s.l. The coefficient of transmissivity in the study area is about $3 \times 10^{-3} \mathrm{~m}^{2} \cdot \mathrm{s}^{-1}$ (Hydrogeological map of the Rye Island, 2005). The groundwater recharge comes mainly from precipitation. The groundwater level is influenced mainly by the Danube River and by precipitation. Although the effective rainfall is very low in the area, the groundwater level is rather high: around $109 \mathrm{~m}$ a.s.l. The groundwater that comes up to the surface is drained by the channel network. The groundwater flow direction is influenced by the water level in the Danube River and the channels. The hydraulics of the Rye Island is affected by the Gabcikovo power plant system, built on the Danube River.

The geometry of the channels (water level, flow width) was obtained by own field measurements and from maps and photographs. The infiltration and drainage resistance of the riverbed sediments in the channels was calculated using data from own field measurements, where the coefficients of permeability were derived from riverbed sediments samples, and the thickness of riverbed sediments were measured every $\mathrm{rkm}$. In the model area no pumping or injecting wells were considered.

\section{Definition of model boundaries}

From North, the model boundary is defined by the Chotarny Channel and the Belsky Channel. The southern boundary is created by Komarnansky and Kratky Channel. From West, the boundary was set to follow an erosion rill and from East a road embankment. The boundary conditions are defined by groundwater heads in boreholes on the boundary and by surface water level in the channels. The situation of model area and the model boundaries are shown in Figure 2. The groundwater heads on model boundary were taken from the database of Slovak Hydrometeorological Institute. Data on surface water level are from own field measurements and from the operating plan of the pumping station on the Chotárny Channel at $0 \mathrm{rkm}$.

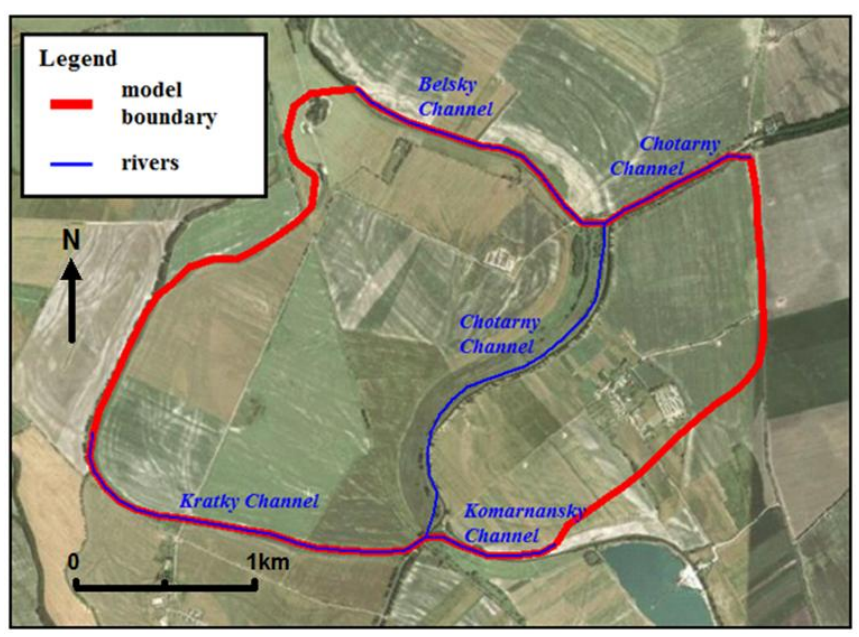

Fig. 2. Map of the model area (Background map source: Google Maps).

\section{Model calibration}

In the calibration process, the model parameters were adjusted to achieve the best fit between observed and simulated hydraulic heads. The observed hydraulic heads were taken from the monitoring network of the Slovak Hydrometeorological Institute. Around the study area three observation wells with long-time mean values of $\mathrm{GW}$ heads were available ( 2 wells from 1960 to 2008, 1 well from 1999 to 2008). The following model parameters were adjusted manually, based on a-priori knowledge: boundary head in aquifer, infiltration and drainage resistance of river sediments, river widths, boundary conditions, precipitation excess, river activity, transmissivity in aquifer, water levels in rivers, boundary flux in aquifer. Detailed information on the model parameters and on the methodology of calibration is given in the TRIWACO Users manual (Royal Haskoning, 2004). During the calibration process it was shown, that infiltration and drainage resistance of the channels sediments are very important parameters, significantly affecting the groundwater flow.We realize that the calibration and the model have limitations, but it was considered to be sufficient for the purposes of this study. Our main interest was to simulate if the channels silting has any influence on the surrounding GW by using the TRIWACO model. To get exact values of GW heads were not as much important.

\section{MEASUREMENT OF CHANNEL NETWORK SILTING UP}

The SW-GW interaction is significantly affected by riverbed silting, clogging or erosion processes. The drainage and infiltration resistance of river bottom sediments depend on the hydraulic conductivity and on the thickness of riverbed sediments. Several field measurements were performed to monitor the silting processes of the channel network on the Rye Island (Velísková and Dulovičová, 2008a; Velísková and Dulovičová, 2008b; Dulovičová and Velísková, 2011b). In this study, the silts hydraulic conductivity and silts layer thickness was used to calculate the resistance parameters of the channels. Consequently, the groundwater heads and the groundwater flow direction in the study area were simulated for different infiltration/drainage resistance parameters.

\section{Thickness of riverbed silts}

The sediments thickness in the Chotárny Channel was measured in 2012 (series of sediment thickness measurements were performed also in year 1993 and 2004). Measurements were done in every rkm along the channel. In the cross-sections the silts thickness was measured with $1 \mathrm{~m}$ step. All measurements were done from the water surface, e.g. the differences between silt top and channel bottom levels were estimated. The detailed methodology of how the thickness of riverbed sediments was measured is described in Dulovičová and Velísková, 2010.

\section{Hydraulic conductivity of silts}

Riverbed sediments samples were taken in the year 2004 at three cross sections of the Chotárny Channel at: $1.2 \mathrm{rkm}$; $12.3 \mathrm{rkm}$ and $25.3 \mathrm{rkm}$. Due to very fine-grained composition and high organic material content of the riverbed sediments it was not possible to take undisturbed samples. From the samples the hydraulic conductivity of silts was determined using empirical 
formulas. There are several empirical relationships for determination of hydraulic conductivity, but their application is limited as many formulas refer to evaluation of undisturbed samples. In this study, the formulas by Špaček (1987) were used to evaluate the saturated silts hydraulic conductivity:

$K_{I}=20.577\left(d_{10}\right)^{1.013}\left(\frac{0.5}{d_{60}-d_{10}}\right)^{0.059}$,

$K_{I I}=108.4386\left(d_{10}\right)^{0.8866}\left(d_{60}\right)^{0.7726}$,

where $K_{I}$ and $K_{I I}$ is saturated hydraulic conductivity [m.day ${ }^{-1}$ ]; $d_{10}$ is particle diameter in $10 \%$ of soil mass [m]; $d_{60}$ is particle diameter in $60 \%$ of soil mass $[\mathrm{m}]$. The particle diameters were determined from granularity curves of the silt samples.

Conditions of validity for application of Equation (4) are:

$$
\begin{array}{ll}
\text { 1. } & d_{10}<0.01 \mathrm{~mm} \\
\text { or } & \\
\text { 2. } & 0.01 \leq d_{10}<0.13 \wedge d_{60}<0.0576+0.5765 d_{10},
\end{array}
$$

and conditions of validity for application of Equation (5) are:

$$
\begin{array}{ll}
\text { 1. } & d_{10} \geq 0.13 \mathrm{~mm} \\
\text { or } & \\
\text { 2. } & 0.01 \leq d_{10}<0.13 \wedge d_{60}<0.0576+0.5765 d_{10} .
\end{array}
$$

From the known values of hydraulic conductivity and layer thickness it is possible to calculate the river resistance parameters and to estimate the infiltration time of water through the layer of silts.

\section{RESULTS}

The outputs of TRIWACO model are groundwater head and flow in the aquifers, flow from rivers and flow from sources. In this study we focused on the level of groundwater head in the aquifer, in dependence on water level changes in the channels and on the resistance parameters of riverbed sediments.

First, the applicability of model TRIWACO was tested in the study area. For this purpose it was considered, that all the watergates are open and the side-channels are not closed from the main (Chotarny) channel. In this case the flow direction of the Chotarny Channel is N-S and all the side-channels flow towards Chotarny Channel. On Figure 3 the map of the simulated groundwater heads isolines is shown. It is clear, that in the model

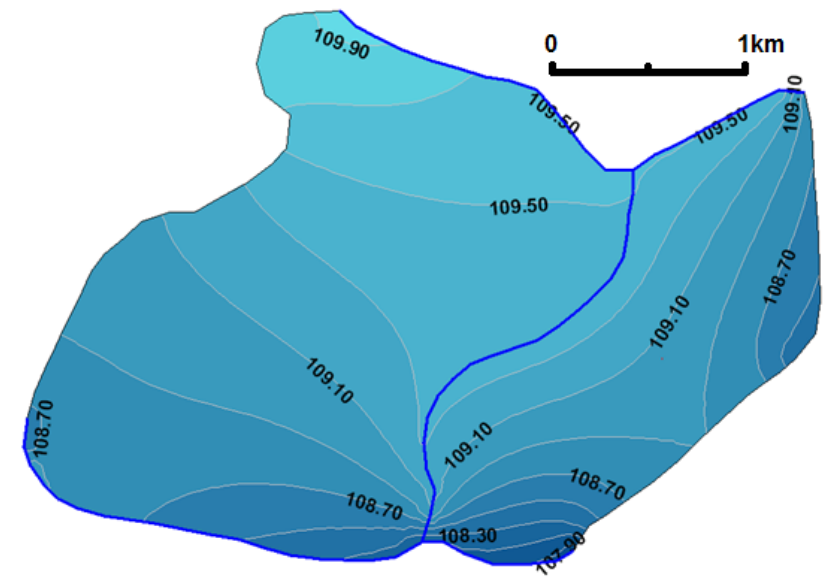

Fig. 3. Contour map of simulated groundwater heads (the darker color represents groundwater heads lower (deeper) under terrain). area the biggest influence on groundwater flow has the Chotarny Channel, which is one of the main channels of the Rye Island channel network. According to the model outputs, the groundwater flow direction in the study area is NW-SE, with maximum levels on NW (109.9 $\mathrm{m}$ a.s.1.) and minimum levels on SE (107.9 $\mathrm{m}$ a.s.1). The average groundwater head in the study area is $109.3 \mathrm{~m}$ a.s.l. The results of the simulation are comparable to those published in hydrogeological maps, what confirms the model applicability in the study area.

Next, we tested the models reaction for different hydrological situations (as it could be_expected). It was simulated how the regulation of water level in the channels influences the GW flow. Different positions of the water-gates and water-level conditions were considered and four model scenarios were created: Scenario A, B, C and D. We checked the response of the groundwater level and flow direction and considered if it was as expected.

In Scenario $A$ no river activity was considered; e.g. it was simulated, what would be the groundwater flow direction and groundwater heads situation if there were no channels in the study area. The contour map of groundwater heads for Scenario A is shown in Figure 4. The outcomes of Scenario A show, that with no surface stream influence the groundwater flow direction in the study area is NW-SE as well, but the global distribution of groundwater level is different. The results of Scenario A are again confirming the fact, that the biggest influence on the groundwater regime in the study area has the Chotarny Channel.

In Scenario $B$ the high-water hydrological conditions were simulated. It was considered, that the water-gates are closed, and so the water from the Chotarny Channel cannot be taken away by the side channels. The initial water level in the Chotarny Channel was set to $110 \mathrm{~m}$ a.s.l.

In Scenario $C$ the low-water conditions in dry periods were simulated. The water level in the Chotarny Channel was considered to be $107.8 \mathrm{~m}$ a.s.l. The water-gates were assumed to be closed, so the main channel cannot be donated by water from side channels. On Figure 5 the simulated isolines of groundwater heads for a) scenario $\mathrm{B}$ and b) scenario $\mathrm{C}$ are displayed. It is visible, that in the high-water level hydrological situations the water from the channel is displaced to the aquifer. On the contrary, in dry periods with the low water level conditions the channel is draining the groundwater from the aquifer, e.g. the groundwater flow direction is towards the channel. These results again confirm the model applicability in the study area as the simulated groundwater flow was as expected.

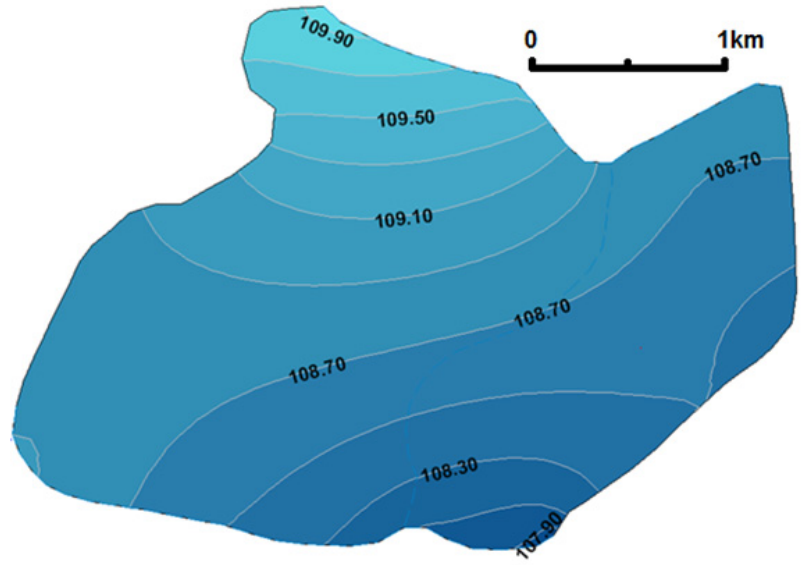

Fig. 4. Contour map of simulated groundwater heads [m a.s.1.] for Scenario A (the darker color represents groundwater heads lower (deeper) under terrain). 


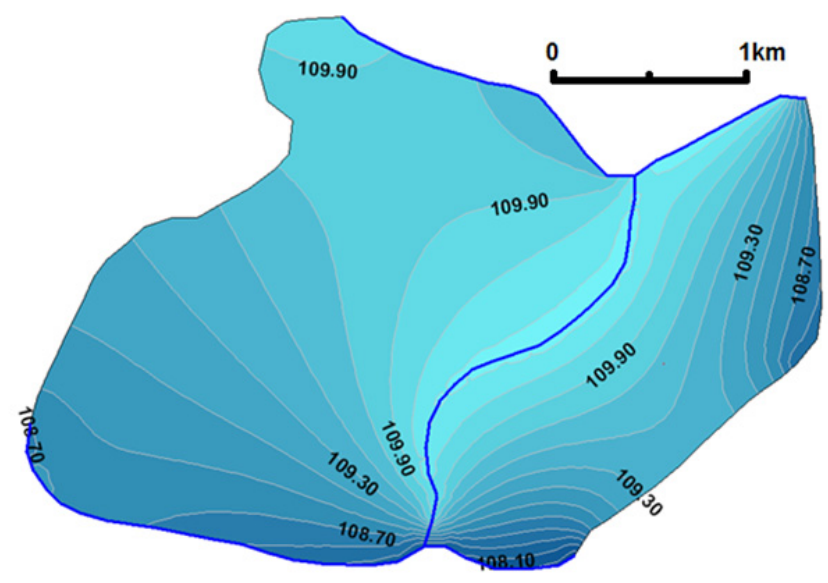

a)

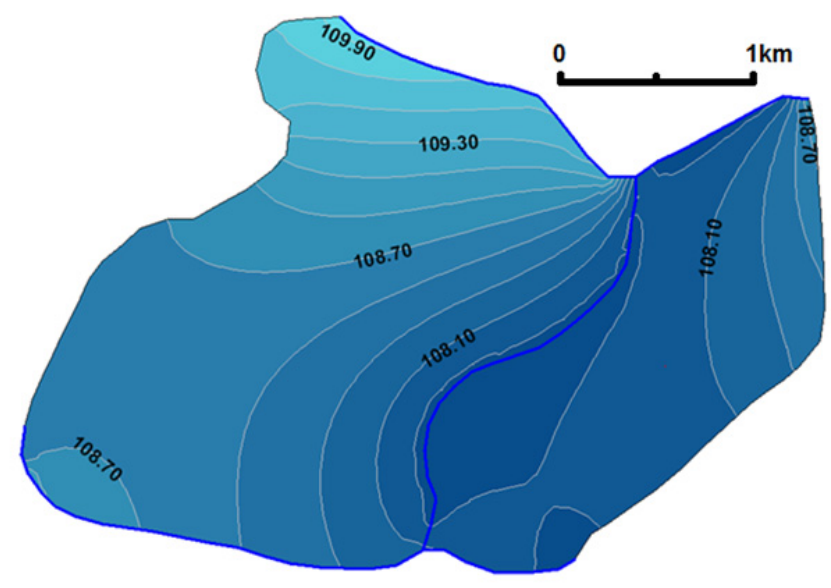

b)

Fig. 5. Contour map of simulated groundwater heads [m a.s.1.] for: a) Scenario B - low-water level hydrological conditions and b) Scenario C - high-water level hydrological conditions (the darker color represents groundwater heads lower (deeper) under terrain).

In model Scenario B and C it was assumed, that high-water hydrological conditions represent bigger hazard in the study area, whereas in this situations the groundwater level can reach the top of the aquifer and overflow the terrain surface. Flooded agricultural areas are more vulnerable to mould diseases of the vegetation, what can negatively influence the crop production in the study area. The influence of low-water periods is not as much notable, whereas the groundwater heads are still relatively high in the area also in dryer periods (around $1.5 \mathrm{~m}$ above the terrains surface).

In Scenario $D$ the influence of a water-gate, built on the Chotarny Channel, on the GW regime was predicted. The contour map of GW heads for Scenario D is shown in Figure 6. Scenario D verified the model sensitivity; the GW heads changed according to the expectations. These outputs confirmed the model possibility to simulate the impact of sudden SW level changes (influence of the closed water-gates) on the surrounding GW heads. It was shown, that the obstruction simulated in Scenario D has the biggest influence on GW regime in the study area, from all of the model scenarios.

Furthermore, the influence of channel network silting up and the sediments layer thickness on the GW-SW interaction in the

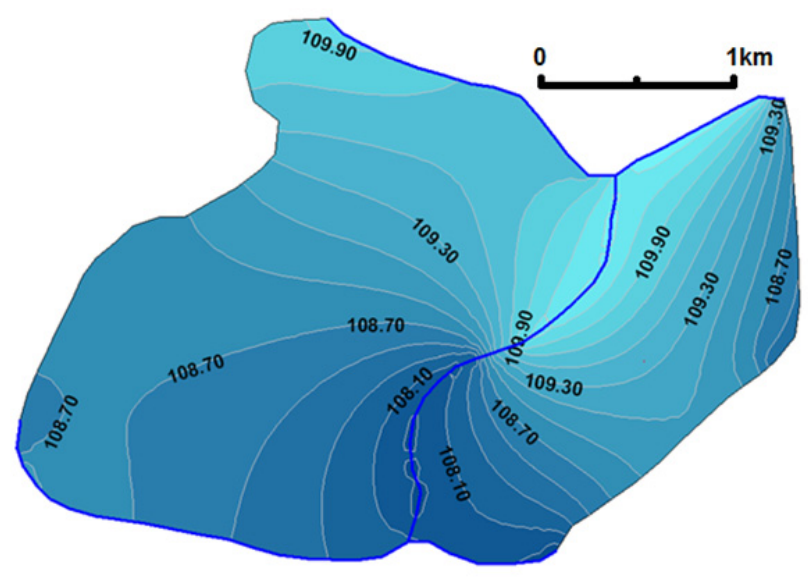

Fig. 6. Contour map of simulated groundwater heads [m a.s.1.] for Scenario D (the darker color represents groundwater heads lower (deeper) under terrain).

study area was modeled. Due to the very low slope and low water flow velocities, the silting up of the channels is intensive in the model area and the water-gates and mild climatic conditions can reinforce this process.

As it was already mentioned, during the model calibration turned out, that infiltration and drainage resistance of the channels are significantly affecting the GW flow in the study area. The GW heads and the GW flow direction were simulated for different infiltration resistance $(C I)$ and drainage resistance $(C D)$ of river (channel) bottom sediments. The $C I$ and $C D$ [days] control the duration of water resources interaction; their values depend primarily on the thickness $(d,[\mathrm{~m}])$ and the saturated hydraulic conductivity $\left(K,\left[\mathrm{~m} . \mathrm{s}^{-1}\right]\right)$ of the clogged layer:

$$
C I, C D=f(K, d)
$$

The riverbed sediment deposits composition is mainly finegrained material: loamy sands, clay and organic material (Dulovičová-Velísková, 2010). The sediments thickness $d$ significantly varies along the channel, in the model area the average value is around $0.45 \mathrm{~m}$. The saturated hydraulic conductivity $K$ was determined by Equation (4) and (5). The value of $K$ at the bottom of the sediments layer is $K_{C D}=$ $4.23 \mathrm{~m}^{-d_{a y}}{ }^{-1}$ and at the top of the layer is $K_{C I}=2.039 \mathrm{~m}^{- \text {day }^{-1}}$. The $C I$ and $C D$ [days] were calculated as:

$$
C I, C D=d / K_{C I, C D} \text {. }
$$

In the model area, the $C I$ of the channels is approximately two-times higher than the $C D$. These results correspond with the suggestions of e.g. Šoltész and Baroková (2010).

The SW-GW interaction processes were simulated in four model scenarios, again, where different channel bed silting up and resistance conditions were assumed:

Scenario E: no sediment deposits, $d=0 \mathrm{~m} ; C I, C D=0$;

Scenario $F$ : sediment layer thickness $d=0.5 \mathrm{~m} ; C I=$ 0.245 day; $C D=0.118$ day;

Scenario $G$ : sediment layer thickness $d=1 \mathrm{~m} ; C I=0.49$ day; $C D=0.236$ day;

Scenario H: sediment layer thickness $d=2 \mathrm{~m} ; C I=0.98$ day; $C D=0.472$ day. 


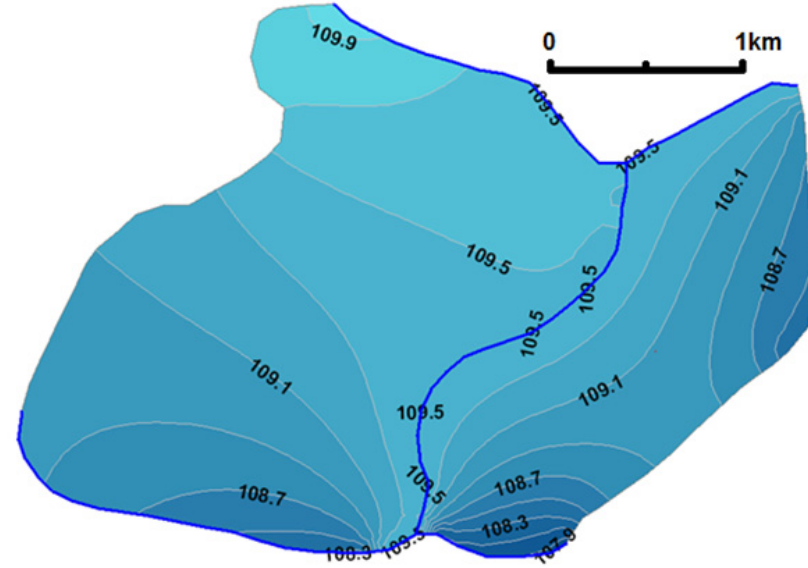

a)

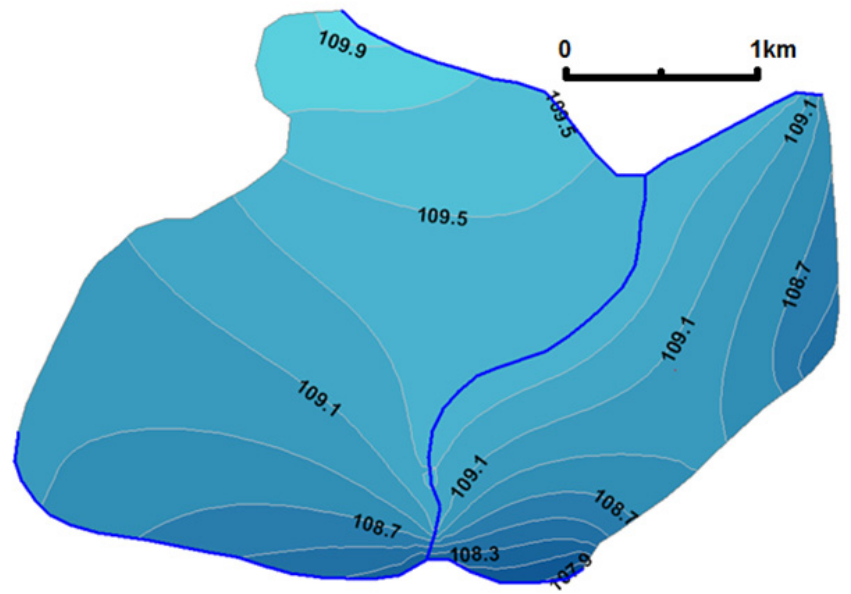

b)

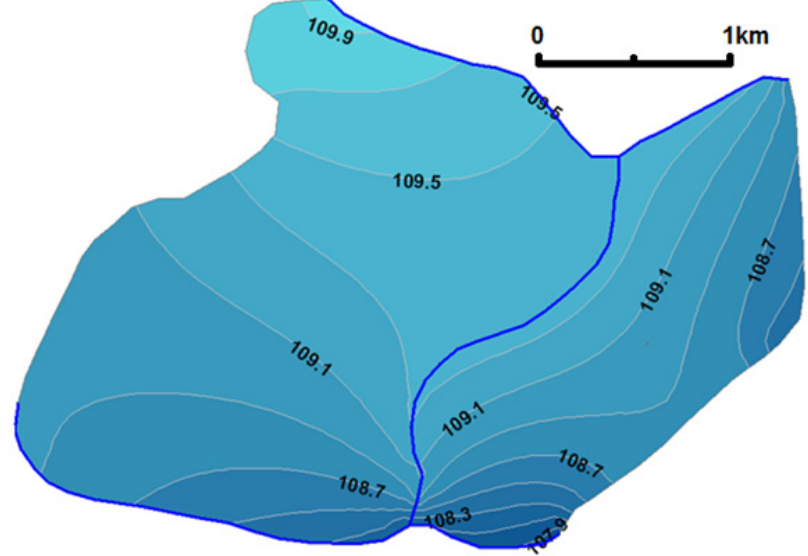

c)

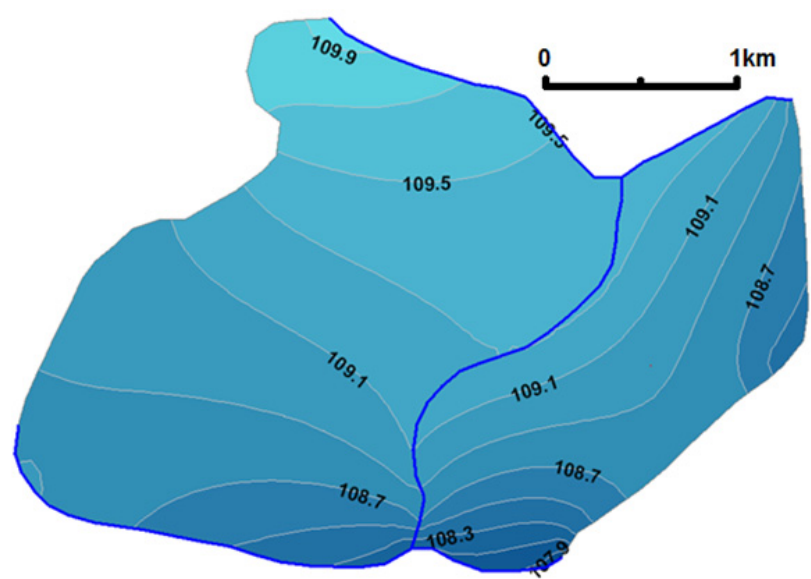

d)

Fig. 7. Contour map of simulated groundwater heads [m a.s.1.] for: a) Scenario E - no sediment deposits; b) Scenario F sediment deposits $=0.5 \mathrm{~m}$; c) Scenario $\mathrm{G}$ - sediment deposits $=1 \mathrm{~m}$; d) Scenario H - sediment deposits $=2 \mathrm{~m}$ (the darker color represents groundwater heads lower (deeper) under terrain).

On Figure $7 \mathrm{a}-\mathrm{d}$, the simulated GW heads for different thicknesses of sediment deposits and different infiltration resistance and drainage resistance of riverbed sediments are shown. Obviously, the thinner the sediments layer is, the less influence on interaction processes it has (Figure $7 \mathrm{a}-\mathrm{b}$ ). In this case the GW heads in the study area are primarily influenced by the water level and flow conditions in the channel. As can be seen, thicker layers of sediment deposits (Figure $7 \mathrm{c}-\mathrm{d}$ ) evidently modify the contour lines of groundwater heads. The biggest influence on the GW heads would have the $2.0 \mathrm{~m}$ thick sediments deposition (Figure 7d). In this case, the effect of the channel on the GW flow is reduced, because the interaction between the channel and groundwater is blocked/clogged by the thick layer of riverbed silts.

\section{CONCLUSIONS}

The objective of this study was testing of TRIWACO ability and applicability for simulation of the SW-GW interaction and the influence of infiltration and drainage resistance of riverbed sediments on the GW regime in a lowland area. The study area has very low slope and the GW level is rather high, therefore a drainage channel system was built up in this locality, where the flow conditions are controlled by water-gates.
It was simulated how the regulation of water level in the channel influences the GW heads and the flow direction in the model area. It was shown, that the biggest influence on $\mathrm{GW}$ regime in the study area has the Chotarny Channel, which is one of the main channels of the Rye Island channel network. In model scenarios the response of GW on high- or low-level hydrological situations in the Chotarny Channel was simulated. It was assumed, that high-level conditions represent bigger hazard for the agriculture and crop production in the study area. The biggest influence on the GW regime would have the water level dammed by a water-gate built on the the Chotarny Channel.

In the model calibration process it turned out, that the channels morphology is of big importance in GW-SW interaction processes in the study area; particularly the sediments layer thickness play dominant role on $\mathrm{GW}$ regime formation. Because of the low slope (only about $2.5 \times 10^{-4}$ ), good climatic conditions for water vegetation and the existing system of water gates built on the channels, the channels are influenced by intensive clogging processes. The thickness and the saturated hydraulic conductivity of the clogged sediments layer influence the infiltration and drainage resistance of riverbed sediments.

In the study, the GW heads and the GW flow direction were simulated for four different sediments layer thickness and channel resistance conditions (no sediments deposit, sediment 
layer thickness $=0.5 \mathrm{~m}, 1 \mathrm{~m}$ and $2 \mathrm{~m}$ ). It turned out, that in the simulations, where no or less sediment deposits were considered the GW heads are primarily influenced by the water level fluctuation in the channels. Layers of sediment deposits thicker than $1 \mathrm{~m}$ have more influence on groundwater regime and evidently modify the contour lines of groundwater heads. In this case, the effect of the channels on the groundwater regime is reduced, because the interaction between the channel and groundwater is influenced by the layer thickness of clogged riverbed sediments and their saturated hydraulic conductivity values.

This study was the first step to test the influence of riverbed sediments deposits on GW-SW interaction in the study area. Although the choosen model TRIWACO is a simple model, it was considered to be suitable to solve this task in the study area. Our main interest was to simulate if the channels silting has any influence on the surrounding groundwater and to demonstrate the effects of channels silting on groundwater flow direction, rather than get exact values of groundwater heads. In further work, it is necessary to improve our knowledge on resistance parameters of channels sediments, to set up a more sophisticated model or to add the application of a model with ability to simulate smaller domain in more details and to perform more simulations in the model area using different river bottom sediments resistance conditions.

Acknowledgements. This publication is the result of the project implementation ITMS 26240120014 Centre of excellence for protection and use of landscape and biodiversity supported by the Research \& Development Operational Programme funded by the ERDF. Furthermore, this work was supported by the VEGA Project No. 2/0123/11.

\section{REFERENCES}

Andrássy, T., Baroková, D., Šoltész, A., 2012. Interaction processes of surface and ground water flow simulated by means of TRIWACO modelling system. In: Colloquium on Landscape Management 2012: Brno, Czech Republic, 3.2.2012. Mendel University in Brno, p. 17-20.

Basic Hydrogeological and Hydrogeochemical Map of the Danubian Plain - Rye Island and the Right Banks of the Danube River at Scale 1:50 000. State Geological Institute of Dionýz Štúr, Ministry of Environment of the Slovak Republic, 2005. (In Slovak.)

Blaschke, A.P., Steiner, K.-H., Schmalfuss, R., Gutknecht, D., Sengschmitt, D., 2003. Clogging processes in hyporheic interstices of an impounded river, the Danube at Vienna, Austria. International Review of Hydrobiology, 88, 3-4, 397-413.

Brunner, P., Simmons, C.T., Cook, P.G., 2009. Spatial and temporal aspects of the transition from connection to disconnection between rivers, lakes and groundwater. Journal of Hydrology, 376, 1-2, 159-169.

Brunner, P., Simmons, C.T., Cook, P.G., Therrien, R., 2010. Modeling surface water-groundwater interaction with MODFLOW: Some considerations. Groundwater, 48, 2, 174-180.

Burger, F., 2007. Modelling and numerical simulation of groundwater flow in the reparian alluvial aquifer. J. Hydrol. Hydromech., 55, 3, 168-184.

Burger, F., 2008. Dependences of the groundwater level fluctuation of the alluvial areas on water level changes in rivers. Acta Hydrologica Slovaca, 9, 2, 274-284. (In Slovak.)
Burger, F., 2011. Change of groundwater flow characteristics after construction of the waterworks system protective measures on the Danube River - A case study in Slovakia. In: Studies on Water Management Issues. INTECH, Rijeka, pp. 53-76.

Cardenas, M.B., Wilson, J.L., Zlotnik, V.A., 2004. Impact of heterogeneity, bed forms, and stream curvature on subchannel hyporheic exchange. Water Resour. Res., 40, 8, DOI: 10.1029/2004WR003008.

Derx, J., Blaschke, A.P., Blöschl, G., 2010. Three-dimensional flow patterns at the river-aquifer interface - a case study at the Danube. Advances in Water Resources, 33, 1375-1387.

Dulovičová, R., Kosorin, K., 2007. Determination of lateral additions of discharges by interaction between open channels and groundwater. Acta Hydrologica Slovaca, 8, 2, 245-253. (In Slovak.)

Dulovičová, R., Velísková, Y., 2010. Aggradation of Irrigation Canal Network in Zitny Ostrov, Southern Slovakia. Journal of Irrigation and Drainage Engineering, 136, 6, 421-428.

Dulovičová, R., Velísková, Y., 2011a. Distribution of silts and some chemical indicators along channel GabčíkovoTopol'níky. Acta Hydrologica Slovaca, 12, 2, 144-150. (In Slovak.)

Dulovičová, R., Velísková, Y., 2011b. Sediment impact on surface water and groundwater interaction at GabčíkovoTopol'níky Channel (Žitný ostrov). In: Proc. XXV Conference of the Danubian Countries on the Hydrological Forecasting and Hydrological Bases of Water Management. VITUKI, Budapest, pp. 1-14.

Fleckenstein, J.H., Krause, S., Hannah, D.M., Boano, F., 2010. Groundwater-surface water interactions: New methods and models to improve understanding of processes and dynamics. Advances in Water Resources, 33, 1291-1295.

Frei, S., Fleckenstein, J.H., Kollet, S.J., Maxwell, R.M., 2009. Patterns and dynamics of river-aquifer exchange with variably-saturated flow using a fully-coupled model. Journal of Hydrology, 375, 3-4, 383-393.

Gutknecht, G., Blaschke, A.P., Herndl, G., Reichel, G., Schmalfuss, R., Sengschmitt, D., 1996. Clogging processes at the storage space Freudenau. Tech. report., IHEWRM, TU Wien. (In German.)

Mallard, F., Tockner, K., Dole-Oliver, M.J., Ward, J.V., 2002. A landscape perspective of surface-subsurface hydrological exchange in river corridors. Freshwater Biology. 47, 621640.

Miklós, L., Kramárik, J., Klinda, J., Lauko, V., Zat'ko, M., Hrnčiarová, T., Mládek, J., Finka, M. (Eds.) 2002. Landscape Atlas of the Slovak Republic. 1st Edition, Ministry of Environment of the Slovak Republic, Bratislava; Slovak Environmental Agency, Banská Bystrica, 344 p.

Peyrard, D., Sauvage, S., Vervier, P., Sanchez-Perez, J., Quintard, M., 2008. A coupled vertically integrated model to describe lateral exchanges between surface and subsurface in large alluvial floodplains with a fully penetrating river. Hydrological Processes, 22, 4257-4273.

Royal Haskoning: TRIWACO User's manual, TRIWACO 3.x, 18 November 2004, Final Report, www.triwaco.com

Šoltész, A., Baroková, D., 2010. Hydroinformatics, $2^{\text {nd }}$ part, Process Simulation of Groundwater Flow in Porous Media. Slovak University of Technology in Bratislava, Faculty of Civil Engineering, Bratislava, 162 p. (In Slovak.)

Špaček, J., 1987: Determination of filtration coefficient from total grain-size curves. Meliorace, 23, 1, 1-13. (In Czech.)

Storey, R., Howard, K., Williams, D., 2003. Factors controlling 
riffle-scale hyporheic exchange flows and their seasonal changes in a gaining stream: a threedimensional groundwater flow model. Water Resour. Res., 39, 2, DOI:10.1029/2002WR001367.

Švasta, J., Malík, P., 2006. Spatial distribution of mean effective precipitation over Slovakia. Podzemná voda, 12, 1, 65-77. (In Slovak.)

Velísková, Y., Dulovičová, R., 2008a. Variability of Bed Sediments in Channel Network of Rye Island (Slovakia). In: Proc. XXIV Conference of the Danubian Countries on the Hydrological Forecasting and Hydrological Bases of Water
Management, Bled, Slovenia. Slovenian National Committee for the IHP Unesco, Ljubljana, $12 \mathrm{p}$.

Velísková, Y., Dulovičová, R., 2008b. Surface water as natural reserves of soil water in Rye Island. Cereal Research Communications, 36, 1, 1595-1598.

White, D.S., 1993. Perspectives on defining and delineating hyporheic zones. Journal of the North American Benthological Society, 12, 1, 61-69.

Received 28 November 2013

Accepted 4 July 2014 